Edited by -Francesca Bregoli,

Carlotta Ferrara degli Uberti, Guri Schwarz
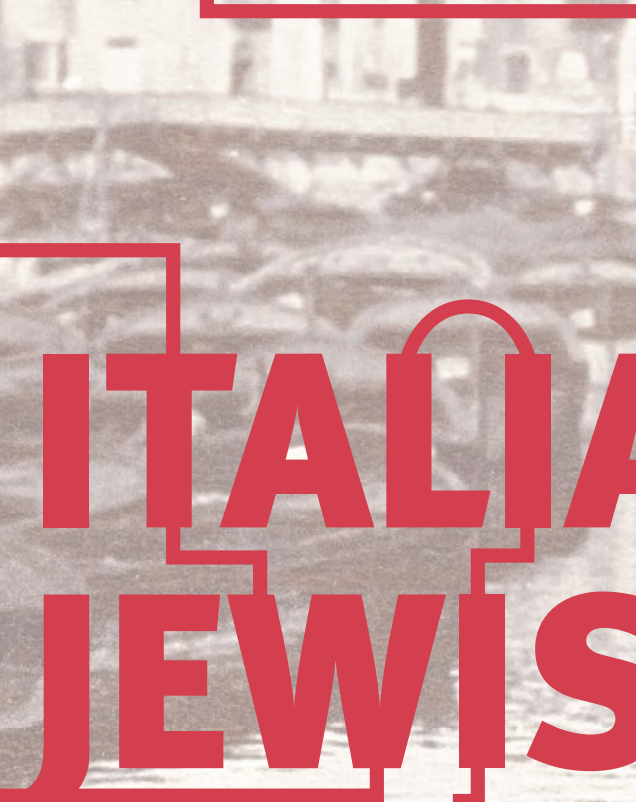
Italian Jewish Networks from the Seventeenth to the Twentieth Century 
Francesca Bregoli

Carlotta Ferrara degli Uberti

Guri Schwarz

Editors

\section{Italian Jewish}

Networks from the

Seventeenth to the

Twentieth Century

Bridging Europe and the Mediterranean

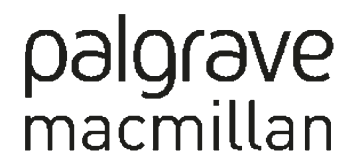




\section{Editors}

Francesca Bregoli

Queens College and The Graduate

Center, CUNY

New York, NY, USA

Guri Schwarz

University of Genova

Genova, Italy

\author{
Carlotta Ferrara degli Uberti \\ University College London \\ London, UK
}

ISBN 978-3-319-89404-1

ISBN 978-3-319-89405-8 (eBook)

https://doi.org/10.1007/978-3-319-89405-8

\section{Library of Congress Control Number: 2018946702}

(C) The Editor(s) (if applicable) and The Author(s) 2018

This work is subject to copyright. All rights are solely and exclusively licensed by the Publisher, whether the whole or part of the material is concerned, specifically the rights of translation, reprinting, reuse of illustrations, recitation, broadcasting, reproduction on microfilms or in any other physical way, and transmission or information storage and retrieval, electronic adaptation, computer software, or by similar or dissimilar methodology now known or hereafter developed.

The use of general descriptive names, registered names, trademarks, service marks, etc. in this publication does not imply, even in the absence of a specific statement, that such names are exempt from the relevant protective laws and regulations and therefore free for general use. The publisher, the authors and the editors are safe to assume that the advice and information in this book are believed to be true and accurate at the date of publication. Neither the publisher nor the authors or the editors give a warranty, express or implied, with respect to the material contained herein or for any errors or omissions that may have been made. The publisher remains neutral with regard to jurisdictional claims in published maps and institutional affiliations.

Cover credit: View of the Venezia quarter, in Leghorn. (C) Alinari Archives / Contributor/ Getty Images

Printed on acid-free paper

This Palgrave Macmillan imprint is published by the registered company Springer Nature Switzerland AG

The registered company address is: Gewerbestrasse 11, 6330 Cham, Switzerland 


\section{Contents}

1 Introduction 1

Francesca Bregoli, Carlotta Ferrara degli Uberti, and Guri Schwarz

2 Rabbi Abraham Rovigo's Home as a Center for Traveling Scholars

Matt Goldish

3 La Puerta de la Franquia: Livorno and Pan-Jewish Networks of Beneficence in the Eighteenth Century

Matthias B. Lehmann

4 Elia Benamozegh's Printing Presses: Livornese Crossroads and the New Margins of Italian Jewish History

Clémence Boulouque

5 Claiming Livorno: Citizenship, Commerce, and Culture in the Italian Jewish Diaspora

Alyssa Reiman

6 Living in Exile: Wissenschaft des Judentums and the Study of Religion in Italy (1890s-1930s)

Cristiana Facchini 
vi CONTENTS

7 Under Observation: Italian Jewry and European Jewish Philanthropic Organizations in 1938-1939

Tullia Catalan

8 Jewish DPs in Post-War Italy: The Role of Italian Jewry in a Multilateral Encounter (1945-1948)

Arturo Marzano

9 Young Italian Jews in Israel, and Back: Voices from a Generation (1945-1953)

Marcella Simoni

Name Index

Place Index 


\title{
Young Italian Jews in Israel, and Back: Voices from a Generation (1945-1953)
}

\author{
Marcella Simoni
}

They never forgot they were Italians; they never forgot their mother tongue and they never learnt good Hebrew. They never stopped eating pasta and drinking coffee, following football games or discussing passionately about the news that came in from Rome, Florence, Turin and Ferrara. Most of all, they remained nostalgic of the historic buildings, of the works of art and of the landscape in which they had grown up. And they always maintained an agonizing dualism that only their children might be able to overcome. (Oriana Fallaci, "Italiani d'Israele," L'Europeo 13, 1973: 136)

M. Simoni $(\bowtie)$

University of Venice, Venice, Italy

e-mail: msimoni@unive.it

(C) The Author(s) 2018

F. Bregoli et al. (eds.), Italian Jewish Networks

from the Seventeenth to the Twentieth Century,

https://doi.org/10.1007/978-3-319-89405-8_9 


\section{Group Portrait of a Generation}

Between 1944 and 1955, about 900 Italian Jews left Italy for Palestine/ Israel $^{1}$ : of these, 621 emigrated shortly after 1948, and about 20 percent of them settled in a kibbutz in the first instance. ${ }^{2}$ This is not the only group of Italian Jews that moved to Palestine in the first half of the twentieth century: some had left Italy already in the 1930s while others fled only after the Racial Laws in 1938; some of them then fled again from Palestine before the War of 1948 (like the Luzzatto family) while others fought in that war (like the Cividalli brothers); some escorted convoys that connected the Western part of Jerusalem to Mount Scopus (like Armando Caimi), or died in the Mount Scopus convoy attack on 15 April 1948 (like Enzo Bonaventura), and others, like Arrigo Levi and Luciano Segre, joined Mabal, the volunteer brigades of the newly established Israel Defense Forces (IDF) in 1948, and then returned to Italy. Many of these histories have already been told in part or in full and reveal a variety of ways in which Italian Jews related to Zionism as a national movement, as an ideal or ideological call, or as a path to refuge before and during World War $\mathrm{II}^{3}$; here, I will focus on the collective experience of that 20 per cent

\footnotetext{
${ }^{1}$ In this chapter I use the term "Palestine" (short for British Palestine) to refer to the country before 15 May 1948; for events occurring after the end of the Mandate, I employ the term "Israel." When I write "Palestine/Israel," I refer to events taking place before and after 15 May 1948.

${ }^{2}$ Arturo Marzano, "Italian Jewish Migration to Eretz Israel and the birth of the Italian Chalutz Movement (1938-1948)," Mediterranean Review 3/1 (2010), 1-29: 18. Guri Schwarz presents slightly different data for the same period, i.e. 1041 Italian Jews emigrating for Palestine/Israel, 161 of which later returned to Italy. See Guri Schwarz, After Mussolini: Jewish Life and Jewish Memories in Post-Fascist Italy (London, Portland: Vallentine Mitchell, 2012), 161.

${ }^{3}$ Arturo Marzano, Una terra per rinascere. Gli ebrei italiani e l'emigrazione in Palestina prima della guerra (1920-1940) (Genoa-Milan: Marietti, 2003); Amos Luzzatto, Conta e racconta. Memorie di un ebreo di sinistra (Milan: Mursia, 2008); Gualtiero Cividalli, Dal sogno alla realtà. Lettere ai figli combattenti. Israele, 1947-1948, ed. Francesco Papafava (Florence: Giuntina 2005); Marcella Simoni, "Gli ebrei italiani e lo Stato di Israele. Appunti per il ritratto di due generazioni (1948 e 1967)," in Roma e Gerusalemme. Israele nella vita politica italiana 1949-2009, ed. Marcella Simoni and Arturo Marzano (Genoa: ECIG, 2010), 47-73; Patrizia Guarnieri, Italian Psychology and Jewish Emigration under Fascism: From Florence to Jerusalem and New York (New York: Palgrave Macmillan, 2016); Arrigo Levi, Un paese non basta (Bologna: Il Mulino, 2009). See also the newly released movie Shalom Italia by Tamar Tal Anati, 2016. Interview by the author with Luciano Segre, Milan, 2 October 2010.
} 
that settled in a kibbutz after World War II, the first group of Italian Jews to do so, that I call here "generation 1948."

This may appear as the story of a small group of youngsters in the process of determining their individual fate, deciding whether to move to Palestine/Israel or remain in Italy after the chaotic and terrible years of World War II. However, because of the times and the particular situation in which this generation grew up, their individual and collective choices placed them at the crossroads of greater questions and relations, which are also the subject of this essay: did the experience of this group help Italian Jewry reconnect to the transformations that Jewish communities around the world were experiencing in the dramatic period between the end of the war, the declaration of the State of Israel, and the War of 1948? And if so, to what extent? Did the call for a practical and socialist Zionism-that this generation responded to-remain a limited case in the relationship between Italian Jews and Zionism? Was it resolved within one generation, or did the experience of this group of youngsters represent the beginning of a longer exchange that gradually invested also the following generations, maybe with different approaches according to the changed historical circumstances? This essay will try to answer some of these questions.

The group that I called "generation 1948" was rather homogenous, first of all in terms of age. Many of them had been born at the turn of the 1930s; in 1938, they had been expelled from schools as a result of the Racial Laws and at home they had encountered the embarrassment of their parents, unable to give them convincing explanations. This group had lived their teenage years during the war, risking deportation, suffering fear and humiliation and often also hunger and deprivation. In his autobiography, one of them, Corrado Israel De Benedetti, remembered how during the war "the noise and the thuds terrif[ied] me and when I la[id] on my net tired at night, I clench[ed] my fists and I wonder[ed] why I have to live in this way at 17 , with the fear of the Germans, of the Fascists and of the Allied planes." 4

After the end of the war, they all shared a strong resentment towards their parents for remaining passive during Fascism and, in some cases, for actively supporting the regime. The histories of Renzo Ravenna and Enrico Paolo Salem, the Jewish Podestà respectively of Ferrara and of

\footnotetext{
${ }^{4}$ Corrado De Benedetti, Anni di rabbia e di speranza 1938-1949 (Florence: Giuntina, $2003), 73$.
} 
Trieste, are well known ${ }^{5}$; without looking so high in the hierarchy of the regime, one can find many other Jews who joined the Fascist party for various reasons, since its establishment in 1921 or from later years: patriotic enthusiasm, economic interests, the possibility to exercise one's own profession, or just adherence to social norms. ${ }^{6}$ Most of those who belonged to "generation 1948 " inevitably had lived their Jewish identity as a heavy burden that they carried in solitude or within the family. As Guri Schwarz has argued, after the war a generational shift emerged. Emanuele Artomwho fought in the Resistance as a young man-defined such gap as an "abyss separating fathers and sons $[\ldots]$ that stops sons from revealing the changes they are going through," to the point that centuries seemed to "separate one generation from another." In this respect, "generation" is not only a term used to define an age group (which is obviously not limited to the 20 percent of Italian young Jews who chose 'aliyah and the kibbutz), but stands here as a synonym of generational self-consciousness, as a way of elaborating one's possible future (over others), considering on the one hand the persecution they had just escaped and, on the other, alternative individual and collective scenarios that post-war reconstruction was showing ahead.

These very same themes emerge also from the words of many who belonged to this group: recalling the war years, Sergio Itzhak Minerbi from Rome, who had been hidden in the Convent of San Leone Magno in Rome during the German occupation, remembered thinking that

${ }^{5}$ Ilaria Pavan, Il Podestà Ebreo. La storia di Renzo Ravenna tra fascismo e leggi razziali (Rome-Bari: Laterza, 2006); Silvia Bon, Un fascista imperfetto. Enrico Paolo Salem, Podestà "ebreo" di Trieste, (Gradisca d'Isonzo: Ed. Centro Gasparini, 2009).

${ }^{6}$ See Luca Ventura, "Il gruppo de 'La Nostra Bandiera' di fronte all'antisemitismo fascista (1934-1938)," Studi Storici 41/4 (2000), 711-755. Alexander Stille, Benevolence and Betrayal: Five Italian Jewish Families under Fascism (New York: Summit Books, 1991), ch. 1. Giulio Supino, Diario della Guerra che non ho combattuto. Un italiano ebreo tra persecuzione e resistenza, ed. Michele Sarfatti (Florence: Inprogress, 2014). See also Italy's Fascist Jews: Insights into an Unusual Scenario, ed. Michele Sarfatti, Quest. Issues in Contemporary Jewish History. Journal of Fondazione CDEC, no. 11 October 2017 available at http:/ /www.questcdecjournal.it/index.php? issue $=11$, accessed 3 January 2018. For an interesting example of Fascist Italian Jews in Tunisia see Archivio di Stato di Livorno, Famiglia Moreno di Tunisi. See also Marcella Simoni, "The Morenos between Family and Nation. Notes for the History of a Bourgeois Mediterranean Jewish family (1850-1912)," in Gender, Nation, Emancipation, Women and Families in the 'Long' Nineteenth Century in Italy and Germany, ed. Martin Baumeister, Philipp Lenhard, and Ruth Nattermann (Oxford: Berghahn, in press).

${ }^{7}$ Quoted in Schwarz, After Mussolini, 70. 
should he "get out alive from this business, I will not stay here [in Italy] one day longer." His words were echoed by those of Corrado Israel De Benedetti from Ferrara, who had decided "not to remain in Italy, because Italy betrayed us," or of Gabriella Luzzati from Genoa; back in school after the war, she "had found an anti-Semitic professor and [...] re-integration was impossible." Remaining in Italy seemed impossible for those who had lost one or both parents to deportation and extermination, as in the case of the brothers Tullio Tzvi and Aldo Eldad Melauri (Adar) from Trieste, and of Bruno Levi from Turin, whose families and father had been deported in 1943. "I did not leave behind such a beautiful world," 8 concluded Donata Ravenna, summing up the situation. This group can also be considered as a separate generation for another reason: confronted with families they despised and with the difficulties of reconstruction and reintegration, they challenged the very notion of belonging to the Italian nation as it had been conceived by their forefathers, and, most of all, they challenged the dream of integration and the myth of equality. ${ }^{9}$ In doing so, they also broke with the tradition of Italian Zionism, which had remained contained in numbers, was traditionally theoretical and philanthropic, and somewhat ambivalent towards personal commitment to immigration. ${ }^{10}$

\footnotetext{
${ }^{8}$ Individual interviews by the author with Sergio Itzhak Minerbi (Jerusalem, 16 August 2009), Corrado Israel De Benedetti (Ruhama, 26 July 2009), Gabriella Luzzati and Aldo Eldad Melauri (Adar) (Ruhama, 30 July 2009), Bruno Levi (Ruhama, 30 July 2009), Donata Ravenna (Haifa, 28 July 2009). As a general rule, I have inserted the Hebrew name that many chose for themselves, or that they received, between given first name and family name. For those who also translated their family name or chose a different one, I have placed it in brackets, next to the Italian family name.

${ }^{9}$ Schwarz, After Mussolini, 76-80.

${ }^{10}$ As it is well known, Italian Zionism suffered from a late start and a small following, if compared with other Zionist movements in Europe. Part of the archives of the Italian Zionist Federation (FSI) are at the Centro di Documentazione Ebraica Contemporanea, Fondo Angelo Sullam and Fondo Leone e Felice Ravenna. On the pre-war period see Marzano, Una terra per rinascere and, for a local example, see Maura Hametz, "Zionism, Emigration, and Antisemitism in Trieste: Central Europe's 'Gateway to Zion,' 1896-1943," Jewish Social Studies, 13/3 (2007), 103-134. The post-war situation is clearly different, at least until 1967. The avant-garde that chose immigration to Palestine/Israel before and after 1948 remained a small group, and, as we shall see in closing, the majority of Italian young Jews opted for a renovated model of philanthropic Zionism and forms of Jewish socialization organized around Italian Jewish institutions, Jewish communities and youth movements. See Schwarz, After Mussolini.
} 
Some 82 percent of the Jews who left for Palestine were younger than $30,{ }^{11}$ and the first boat that left Italy with Jews on board (among them 158 Italian Jews) sailed on 25 March 1945. The geographical provenance of this group was varied enough to be considered altogether representative of the distribution of Italian Jewry, with an obvious imbalance towards the Center and the North, a reflection of the historical distribution of Jews along the peninsula.

In 1946 this generation of young Italian Jews established Hechalutz (the Pioneer), an inclusive pioneering youth movement. Through its ranks, in various yearly waves, many of them settled in a kibbutz. The movement operated until 1956 and published a fortnightly homonymous newspaper until 1953, when the first signs of a generational, and possibly political, crisis started to appear: the publication became monthly and the hakbsharah (training farm) of Tel Broshim (hill of the cypresses, also known as San Marco) at Cevoli (Pisa)—which had been originally sponsored by the UCII, the Union of the Italian Jewish Communities, and where most of these youths had trained together since 1946-closed. At the beginning of the 1950s, this group also witnessed the first returns to Italy.

The history of "generation 1948" and of the group who chose the kibbutz is relational per se, if we look at how they redefined their existence and identity as individuals and as a peer group. Their choice was political and existential at the same time, embracing Socialism (and Communism for some) and collectivism over their middle-class background; it was also national, as they became Italkim, ${ }^{12}$ rather than remaining Italian Jews as their families before them. Such a deep individual and collective transformation was the result of multiple influences. Some of these came from outside, whether in geographical or cultural terms, and they are discussed in the first part of this essay; others were the result of dynamics that developed inside the group; these will be discussed in the second part of this chapter. In any case, the history of "generation 1948" was-and remains to this day- the history of a collective experience.

${ }^{11}$ Marzano, "Italian Jewish Migration to Eretz Israel,” 18.

${ }^{12}$ Italki; pl. Italkim translates as "Italian/s" from modern Hebrew. In time, the term denoting the national provenance/belonging has acquired the marker of a specificity within the broader ethnonational definition of Israeli, as in many other cases (Polanim, Yekkes, Russim). The presumed particular role of the Italkim in Israel is discussed in La Rassegna Mensile di Israel, 80/2-3 (2014/5775), ed. Sergio Della Pergola, Cecilia Nizza and Angelo M. Piattelli. 
In an article of 1946, a young member of Hechalutz, Mirella Tedeschi, summarized in rigmarole these internal and external influences that determined the uniqueness of this experience as it was being shaped by a youth movement:

Hechalutz? Hechalutz is something, something for sure, but what it is remains unclear. Hechalutz are the Palestinian soldiers (what a nice uniform and what tasty chocolate!) and the girls cannot resist them [...] Hechalutz? Hechalutz is something, something for sure, but what it is remains unclear. Hechalutz are girls and boys without the soldiers [...] Only one thing is known, that they are mad, but seriously mad. Imagine they want to go to Palestine. Have you ever heard something like that? Leaving their parents, their studies, their home $[\ldots]$ Hechalutz? Hechalutz is something, something for sure, but what it is remains unclear. Hechalutz are girls and boys who believe they are adults: they print newspapers, they convene conferences, they go here and there, they say "we chalutzim," they have a statute, they go to conferences [...] Hechalutz? Hechalutz is something, something for sure, but what it is remains unclear. Hechalutz are people who want to go to Palestine $[\ldots]$ But it is so good to stay here! And Palestine is for refugees, orphans, widows and the crippled $[\ldots]$ Hechalutz is that institution that steals our children, say the parents; Hechalutz is the place where these boys and girls are all shaken up, say grannies; Hechalutz is that place that I do not attend, say aristocrats; Hechalutz is those people that create antisemitism, say assimilated Jews. Hechalutz is a movement, say the chalutzim, is an idea, a norm of life and of thought, is a continuous drive, it is sacrifice and joy, is clarity and ascent $[\ldots] .^{13}$

\section{EXTERNAL INFLUENCES AND RELATIONS}

Various external factors influenced "generation 1948" towards emigration to Palestine/Israel: the presence on Italian soil of the Jewish Infantry Brigade Group (JB), and various emissaries (shelichim) arrived from Palestine/Israel to favor and organize such immigration. ${ }^{14}$ Another institution that helped substantially in the reconstruction of Jewish life in Italy-and thus indirectly also helped some Italian and some foreign Jewish youth move to Palestine-was the Jewish Joint Distribution

${ }^{13}$ Mirella Tedeschi, "Hechalutz è...," Hechalutz 1/3, 6 Tammuz 5706 - 5 July 1946: 4.

${ }^{14}$ For a very interesting comparative case, see Chaya Brasz, "Expectations and Realities of Dutch Immigration to Palestine/Israel After the Shoah," Jewish History, 8/1-2 (1994), $323-338$. 
Committee (JDC), whose emissaries arrived in Milan on 30 April 1945, just five days after insurrection and liberation, and immediately set to work in cooperation with the JB and local Jews.

The history of the JB is very well known ${ }^{15}$ : established in 1944 , and originally headquartered in Egypt, it saw about 5000 Jews from Mandatory Palestine enlist as volunteers. It was adjoined to the British Eighth Army in the Italian Campaign of 1944-1945, it fought in combat, and was then stationed in Tarvisio after 1945, close to the border between Italy, Austria, and former Yugoslavia. It was then dispatched to Belgium and Holland and ultimately disbanded in 1946. Beyond combat, the JB had a tremendous impact among Italian Jews. It had a positive psychological effect on those (especially young or teenage) Jews that it encountered, often by chance, and a practical one once the war was over, helping Italian and foreign Jews locate survivors; it served as an organizational task, favoring some embryonic forms of Jewish collective life in liberated areas; and it offered an ideological/national purpose, organizing the so-called berichah, the illegal flight of European Jewish survivors towards Palestine from Italy's liberated Southern ports, ${ }^{16}$ and encouraging youth to settle in Palestine.

In various ways, most testimonies of Jews who encountered the soldiers of the JB tell of the combination of these aspects. ${ }^{17}$ Marco Maestro for example, another member of "generation 1948" who immigrated to Israel in 1952, recounted how his "contacts with the movement Hechalutz start[ed] in 1944, with the arrival in Florence of the Chaialim (sic) [soldiers of the JB]."18 With the liberation of Rome on 4 June 1944, the JB helped establish a center close to the synagogue, in Via Balbo 33, whose activities and significance for the re-foundation of a Jewish community in Rome have been described extensively by Sergio Itzhak Minerbi, one of

${ }^{15}$ See the documentary by Chuck Olin, In Our Own Hands. The Hidden Story of the Jewish Brigade in World War II, 1998, available at http://mediaburn.org/video/in-our-ownhands-the-hidden-story-of-the-jewish-brigade-in-world-war-ii/, accessed 1 November 2016.

${ }^{16}$ Yehuda Bauer, Flight and Rescue: Brichah (New York: Random House, 1970); Ada Sereni, I clandestini del mare (Milan: Mursia, 1973); Mario Toscano, La "Porta di Sion." L'Italia e l'immigrazione clandestina ebraica in Palestina (1945-1948) (Bologna: Il Mulino, 1990); Idith Zertal, From Catastrophe to Power: Holocaust Survivors and the Emergence of Israel (Berkeley: University of California Press, 1998).

${ }^{17}$ La Brigata ebraica in Romagna 1944-1946. Attraverso il Mediterraneo e l'Italia per la libertà, Quaderni del Museo Ebraico di Bologna/5, ed. Franco Bonilauri e Vincenza Maugeri (Rome: De Luca Editori D'arte, 2005), 45, 49-50.

${ }^{18}$ Marco Maestro, Un Kaddish per Stalin, http://www.hakeillah.com/5_03_37.htm. 
the center's organizers, and by others. ${ }^{19}$ Here came to life the first (CenterSouth) branch of what would become a national pioneering youth movement Hechalutz and its newspaper (originally appearing as "Dapei Hechalutz" in two separate editions, one for Rome and one for Milan). As for Milan, Cinzia Villani has discussed the establishment of a center for Jewish DPs in Via Unione 5 and the joint role of the JB, the JDC, and some notable local Jews in this enterprise. This was neither connected to the movement Hechalutz, nor did it lead directly to the re-foundation of Jewish life there. Still, it was another example of how important were the relations between these different local and international bodies for the rebirth of an organized Jewish life in Italy, whether as a direct result of their efforts, or as an indirect cause of collective action and cooperation. ${ }^{20}$ A similar cooperative effort gave life to the children's home of Sciesopoli in Selvino (Bergamo), a facility where about 800 Jewish orphans from Eastern Europe spent some time in preparation of their immigration to Palestine/Israel between 1945 and $1948 .{ }^{21}$

The JB was also instrumental in setting up hakbsharot (training farms) in Italy where youths combined the study of Hebrew and of life in Palestine from the Zionist perspective of the times (called Palestinography), and agricultural practice. The hakhsharah had proven a valid instrument in Eastern Europe, favoring the construction of strong bonds within the group undergoing training and leading to the formation of nationally committed youths, becoming one of the standard means to channel new recruits for the Zionist movement from the 1910s onwards. ${ }^{22}$ In Italy there had been a few hakhsharot between 1934 and 1938, when small

\footnotetext{
${ }^{19}$ Sergio I. Minerbi, "L'Hechaluz in Italia dopo la Liberazione," in Verso una terra "antica e nuova." Culture del sionismo (1895-1948), ed. Giulio Schiavoni and Guido Massino (Rome: Carocci Editore, 2011), 261-287. Marzano, "Italian Jewish Migration to Eretz Israel.”

${ }^{20}$ Cinzia Villani, “Milano, via Unione 5. Un centro di accoglienza per 'displaced persons' ebree nel secondo dopoguerra," Studi storici 50/2 (2009): 333-370. On the international networks operating in Italy for Jewish DPs see Chiara Renzo, “ 'Our Hopes Are Not Lost Yet.' The Jewish Displaced Persons in Italy: Relief, Rehabilitation and Self-understanding (1943-1948)," Quest. Issues in Contemporary Jewish History, 12 (2017): 89-111.

${ }^{21}$ The facility was rented by Raffaele Cantoni in 1945 and run by the JB until 1948. Aharon Megged, The Story of the Selvino Children (London: Vallentine Mitchell, 2001) and http://www.sciesopoli.com, accessed 1 November 2016. See also Sergio Luzzatto, I bambini di Moshe (Turin: Einaudi, 2018).

${ }^{22}$ Henri Near, A History of the Kibbutz Movement, Volume 1: Origins and Growth 1909-1939 (Oxford: Oxford University Press, 1992).
} 
groups of German, Polish, Czech, and Hungarian young Jews found in Tuscany a precarious refuge before most of them obtained immigration certificates to Palestine after one year of training; however, at that time, this kind of pioneering socialism had not really awaken much interest in Italian Jewish youths. ${ }^{23}$ With the post-war hakhsharot, therefore, and with the establishment of its first pioneering youth movement, "generation 1948" belatedly embraced some of the pillars of labor Zionism, among them promoting the spiritual and physical regeneration of the Jews through manual and agricultural labor, the transformation of the Jewish middle classes into a socialist community of workers, the idea that such transformation would bring about the normalization of the Jewish people, and, last but not least, the creation of the new individual. ${ }^{24}$ The first hakbsharot were mainly for Jewish refugees transiting in Italy and were set up and managed by soldiers of the JB. ${ }^{25}$

The influence of relations of external agents and actors was not limited to the JDC and the JB; another factor that weighed on the experience of "generation 1948" was the arrival of some Italian emissaries (shelichim) from various organizations and kibbutz movements after liberation. Umberto Nahon (who had emigrated to Palestine in April 1939) arrived in Italy in February 1945 on behalf of the Jewish Agency, and set up the Palestinian Office of Rome issuing visa certificates to emigrate to Palestine. Marcello Malkiel Savaldi-who had left Trieste for Palestine in 1938 and was among the founders of kibbutz Givat Brenner where other Italkim had settled after 1938-arrived in the fall of 1945; he came on behalf of the Kibbutz Ha-Meuchad Movement (United Kibbutz, 1927, originally associated with Po'ale Zion and Achdut 'Avodah). ${ }^{26}$ His brother, Bruno

\footnotetext{
${ }^{23}$ Carla Forti and Vittorio Haim Luzzatti, Palestina in Toscana: pionieri ebrei nel Senese (1934-1938) (Florence: Aska 2009); in July 1939 two hakbsharot for young Italian Jews were established in Orciano and Cevoli (Pisa). These were closed by the authorities following an order of the Carabinieri on 3 May 1940. On Italy as a refuge for Jews between 1934 and 1938 and hakhsharot see Klaus Voigt, Il rifugio precario. Gli esuli in Italia dal 1933 al 1945 (Florence: La Nuova Italia, 1993), 220-240.

${ }^{24}$ For this kind of language and rhetoric, see, among the many possible examples, Tullio Melauri, "Vita di Hechalutz. Da Trieste," Hechalutz 1/2, 21 Sivan 5706 - 20 June 1946: 4 and F.L. "Che cosa faremo in Eretz," Hechalutz 1/6, 24 Elul 5706 - 20 September 1946: 2; Nora Bolaffio, "La crisi della gioventù," Hechalutz 2/1, 12 Tishri 5707 - 7 October 1946: 3.

${ }^{25}$ Alex [Alessandro Sternberg], "Hechalutz dei profughi," Hechalutz 1/3, 6 Tammuz 5706 - 5 July 1946: 2.

${ }^{26}$ See Marcello Savaldi, “Ricordi di Via del Monte," La Rassegna Mensile di Israel, 38/7-8 (1972): 193-195. Marcello Savaldi had also been one of the few that had promoted a pio-
} 
Savaldi, had entered the country as a soldier of the JB. Yosef Galili from kibbutz Messilot came as shaliach of the Kibbutz Artzi Movement (National Kibbutz, 1927, associated to the Marxist-Zionist political party Mapam), though it was Silica Cahana (1923-1948)—a Romanian refugee based in the DP camp of Avigliana near Turin, who operated informally as representative of the $\mathrm{Ha}$-Shomer $\mathrm{Ha}$-Tza ir youth movement $\mathrm{HH}$, socialist-Zionist) and thus also of Kibbutz Artzi. Silica left an indelible impression on the young Jews of "generation 1948" who met him, to the point that Bruno Gad Segre created a new Italian verb to describe him and his work: "he fell upon us in Turin and silicated (sic) us all." 27 With his personality, enthusiasm, and personal example, he succeeded in attractingalmost seduce-many Italian young Jews, initially from Turin and Northern Italy, and then from other parts of the country too. His myth is very much alive with many of "generation 1948" until today: he is remembered falling on the battlefields of the War of 1948 singing the Italian communist song Bandiera Rossa, on 24 May 1948.

Other emissaries arrived, among them Max Varadi (Meir Vardi) and Nurit Ravenna from kibbutz Sde Eliyahu—-thus affiliated with the Kibbutz Ha-Dati (the Religious Kibbutz Movement). Last but not least, arrived Leo Levi, representing the Irgun Olei Italia (sic, Organization of Immigrants from Italy) that had been established in $1939 .{ }^{28}$ The arrival from Israel of emissaries representing different movements/political parties and their quite frantic activities among young Italian Jews and within Jewish communities to attract as many youngsters as possible can be seen as a sign of a reconnection between the major trends of Zionism at the time and Italian Jewry, and the moment in which an altogether marginal and provincial group of Jews started to be reincorporated and to realign itself into a broader Zionist picture. In order to pull as many recruits as

neering approach to youth education already in the 1930s, before his migration to Palestine. See Marcello Savaldi, “I campeggi ebraici: 1931-1939," Storia Contemporanea, 6 (1988): 1121-1152.

${ }^{27}$ Interview by the author with Bruno Gad Segre, Haifa, 28 July 2009. "Silica era un profugo attivista di Ha-Shomer Ha-Tza'ir che è piombato a Torino e ci ha silicato tutti." See also the letter from Bruno Gad Segre to Silica on 10 April 1947 in Istituto Nazionale per la Storia del Movimento di Liberazione in Italia, Milano (henceforth INSMLI), Collection Guido Valabrega, Folder 20/1.

${ }^{28}$ On Leo Levi, see Contro $i$ dinosauri. Scritti civili 1931-1972, ed. Arturo Marzano (Naples: L'ancora del mediterraneo, 2011), and the documentary film by Yaala Levi Zimmerman, Leo Levi - The Man with the Nagra, 2011. 
possible towards their movement's settlements, each of them played their tunes: at one edge of the spectrum stood Savaldi and Varadi-Ravenna vouching respectively for kibbutz Givat Brenner and Sde Eliyahu, convinced that a new 'aliyah of young Italian Jews should go where an Italian presence had consolidated in previous years; another argument was put forward in favor of the religious kibbutz, namely that in that movement middle-class parents would be reassured about the future of their rebellious sons and daughters. ${ }^{29}$ At the other edge stood Cahana who, on the contrary, argued that they should settle in a new and/or in a frontier community, in line with the process of physical and political regeneration they had embraced in hakhsharah. As we shall see below, most of "generation 1948" ended up settling in a kibbutz of the Kibbutz Artzi Movement. Sergio Itzhak Minerbi- one of the older members of this generation, and one of the first to arrive in Palestine/Israel on 1 August 1947-claims the merit of diverting this Italian 'aliyah from Givat Brenner or Sde Eliyahu to kibbutzim of the Kibbutz Artzi. ${ }^{30}$ In a letter to Guido Gadi Valabrega, a young member of the community of Turin, he wrote:

As long as there remain two separate kibbutz organizations (K. Ammeuchad and $\mathrm{K}$. Arzì) (sic), and this separation will certainly continue for years to come, we must educate the chaverim [members/comrades] (sic) to kibbuz arzì $(s i c)$. It is not enough to be content with adhering politically to MAPAM. It is sufficient for those who will contribute to the socialist construction only with their electoral vote. But for those chaluzim [pioneers] $(s i c)$ who want to implement their ideas instead, and actually live a socialist life, there is the problem of the choice of the kibbuz $(s i c)$. [...] And this is the problem that we must begin to lay before the chaverim (sic) right now, so that they do not find themselves unprepared tomorrow before any Savaldi. ${ }^{31}$

On 29-30 April 1946, at the conference of Ceriano Laghetto, the Center and Northern branches of Hechalutz merged in a united and national youth movement. This process responded to the aspirations of many young Jews to be affiliated on a national scale, and to their belief that Italian Jewry should remain united in view of its limited numbers and of its tradition of inclusiveness. For the time being, the competition of the

\footnotetext{
${ }^{29}$ Interview with Melauri (Adar) and Gabriella Luzzati.

${ }^{30}$ Minerbi, "L'Hechaluz in Italia dopo la Liberazione," 276-285.

${ }^{31}$ INSMLI, Collection Guido Valabrega, folder 7, Letter from Sergio Izhak Minerbi to Guido Gadi Valabrega, Rome, 4 March 1949.
} 
shelichim for recruits had caused a reaction against ideological/political fragmentation. As we shall see, this lasted until the early 1950s, when the unity of intents and aspirations of this group broke when it was confronted with the ideological and political rifts that split the kibbutz movements between 1952 and 1953. The celebrated unity of the Italkim stood strong until they migrated to Israel where they were absorbed into the scorching political climate and debates of the times and of the place. ${ }^{32}$

\section{INTERNAL INFLUENCES AND RELATIONS}

As mentioned above, a first group of young Italian Jews arrived in Palestine before a youth movement was established in Italy; among them, 34 did their hakbsharah in Degania $\mathrm{A}^{33}$ next to a group of French Jews training in Degania B. The Italkim and their peers who were organizing hakbsharot in Italy corresponded regularly: the former produced a home-made journal, entitled "LeIedidenu" [To Our Friends], in which one can read the first impressions of middle-class Jews parachuted into an agricultural settlement whose standing was mythical in the history of Zionism. This group struggled to integrate with migrants who had arrived a few decades before, generally from Eastern Europe. With the exception of Armando Caimi from Trieste, whose family originated in Corfu and who had a

\footnotetext{
${ }^{32}$ The rifts were not only on the left of the political spectrum, but also between secular and religious kibbutzim. Arturo Marzano reports that already in 1947 the Chevrat Yehude Italiyah le-Pe'ulah Ruchanit Yerushalayim [the Association of Italian Jews for spiritual action-Jerusalem] had criticized the non-religious kibbutzim in a small booklet; this provoked the angry response of the secular members of the "Irgun Olei Italia." See Marzano, "Italian Jewish Migration to Eretz Israel," 25.

${ }^{33}$ Rachel Baruch, Armando Menachem Caimi, Adele Calò, Germana Calò, Silvio Gershon Calò, Umberto Ya'akov Calò, Elda e Aldo Campagnano, Arduino Caro, Arrigo Tzvi Caro, Emma Cortesi Sonnino, Enzo Mosheh Cortesi (the latter two married in Degania A on 18 May 1945), G. Zev Di Porto, Leo Arieh Disegni, Carla Rivka Gomez de Silva, Benzion Koenig, Yehudit Kun, Ilse Mandel, A. Shlomo Mariani, Laura Ester Milano, Sara Milano, R. Hillel Millul, Dalia Millul Anticoli, G. Lot Minerbi, Liliana Pacifici, Gianna Popper, Letizia Chava Popper, G. Mosheh Rosenwass, Nathan G. Rossi, Tullio Shmuel Segre, Ferruccio Barzilai Sonnino (Bar-Yosef), Dvorah Sonnino, Adolfo Efraim Ventura, Miriam Ventura. The group included four others who, upon arrival, enlisted in the JB-Sergio David Amati, Sigfrido Ariel Cardoso, Elio Eliahu Millul, and Ya'acov Weiss (Fiume)-and a madrikh (group leader) from nearby kibbutz Puriah, Lucio Yair Levi. Archives of the Jewish Community of Trieste (AJCT), Collection Caimi, LeIedidenu, Luglio 1945, n. 1. Giornale del gruppo Degania A., "Notizie sul Gruppo," 18-20.
} 
working-class background, ${ }^{34}$ they all came from middle-class families and 15 of them went back to Italy after a while. They had no experience in manual work, they were not accustomed to the climate, spoke little Hebrew and no Yiddish, and adapted to the hard working conditions with difficulty. The difference between them and the inhabitants of the kibbutz could not go unnoticed, at work for example: Aliza Ilse Mandel told her friends doing hakhsharah in Italy about how difficult it was to keep the pace of work in the fields with the "sabras that work with ease and swiftly," and of how hard she tried, to the point of fainting under the scorching sun, remaining idealistically committed to her "adored Land." 35 The differences were evident also by looking at their recent pasts: Ferruccio Barzilai Sonnino described the inhabitants of Degania as "educated in an atmosphere of freedom and balance, as sons of the independent agricultural colony" while they "had spent the last few years in hiding." At the same time, he described the "culture of the country" as "closed," and themselves as a group "who had studied Greek and Latin, read Dante, listened to Chopin and Wagner," suffering from the "intellectual emptiness" that they perceived around them. ${ }^{36}$ Another member of this group, Silvio Gershon Calò, observed the differences on a more general level:

Eastern European Jews have indeed built Eretz Israel but they brought here a reaction against a terrible slavery that they suffered for centuries; they have known the pogroms and the manhunt by the Cossacks and of the Ochrana [Czarist Secret Police]; they have known the dark atmosphere of revolutionary anti-czarist circles, the misery and hunger of the small villages, the exalted mysticism of the chassidim (sic) and the anti-religious rebellions of youth at the beginning of the century. Maybe for this reason Eretz Israel is so full of extremism.

The tradition of Italian Jewry could not be more distinct, continued Calò, as it

\footnotetext{
${ }^{34}$ I have described the tragic story of Armando Caimi and analyzed the correspondence between him in Palestine and his family in Italy in Simoni, "Gli ebrei italiani e lo Stato di Israele."

${ }^{35}$ AJCT, Collection Caimi, LeIedidenu, Luglio 1945, n. 1. Giornale del gruppo Degania A., Aliza Ilse Mandel, "La malattia dell'idealismo," 13.

${ }^{36}$ Ibid., Ferruccio Barzilai Sonnino, "Incontro con un altro mondo," 7-10: 7 and ibid., Baiah Baraz, "Parla una figlia di Erez Israel," 10.
} 
has always been [based on] respect and mutual understanding, a trend towards unity and the smoothing of ideological differences; Italian Judaism has always been against extremes; it always found a way that could be walked by an orthodox and heterodox, the socialist and the middle class, the idealist and the one inclined to practicalities. ${ }^{37}$

When "generation 1948" established the youth movement Hechalutz in Italy, it also followed the same unitary approach, and the inclusive hakhsharah of Tel Broshim became its main means of immigration to Palestine/ Israel. Still in Italy at the time, and writing about that period much later, the future historian and intellectual Corrado Uri Vivanti (Chaim) from Mantova remembered how the movement "dispensed with all distinctions of parties," because of "the scarcity of Italian forces," but also to bring "vital energy for the action of the movement." 38 The relationship between the movement and the hakhsharah was symbiotic; one nourished the other, in diverse ways and intensity in different periods of time. In order to attract as many young Italian Jews as possible, in 1946 Savaldi wrote in the journal "Hechalutz" of the connection between the two:

Hechalutz $[\ldots]$ is the result of the union of those young Jews who actually wanted to get ready to build Eretz Israel through their work. [...] And there isn't a more stringent form of life, and more freedom at the same time, than the one made by halutzim in their hachsciarà $(s i c)$ centers, and even more in the kibbutzim of Eretz Israel. Therefore these centers of new life exert an extraordinary fascination for all who approach them. ${ }^{39}$

The hakbsharah of the movement Hechalutz (Tel Broshim or San Marco) opened in 1947. It was a farm owned by Giulio Racah (later Israel Prize for physics); it had fields, a barn, some animals and it came with Pellegrino Lippi, the farmer who tried to teach agriculture and transform these urban youngsters into socialist workers. ${ }^{40}$ A small paper, "Darkeinu" [(sic), Our Way], was also published at Tel Broshim. Approximately after one year of training, from here "generation 1948" migrated to Israel in

\footnotetext{
${ }^{37}$ Ibid., Silvio Ghershon Calò, "LeIedidenu," 2.

${ }^{38}$ Corrado Vivanti, "Ricordi dell'Hechaluz," http://www.hakeillah.com/5_03_36.htm, accessed 5 November 2016.

${ }^{39}$ Malkiel Savaldi, "Hechalutz. Sue origini ed essenza," Hechalutz 1/3, 6 Tammuz 5706 5 July 1946: 2.

${ }^{40}$ Some pictures of Tel Broshim are available at INSMLI, Collection Valabrega, folder 290.
} 
classes or cohorts, organized by year. As Aldo Eldad Melauri (Adar) said, pointing to himself and to his wife Gabriella Luzzati: "We were like wine. I am year 1949; she is year 1950." 41

The exchange between the group doing hakbsharah in Italy and the one that immigrated to Israel was continuous, and took various forms. They corresponded, writing individual and/or collective letters. Each group described their collective life, updated the others on the decisions of the assembly and of the leadership, on the newcomers, their functioning as a group, on some inevitable difficulties, some equally inevitable love affairs, and so on. Those in Israel described their experiences: the practical and ideological question of manual work, their encounters with Jews from Arab countries, and some aspects of the country's domestic policies; they also insisted that those who seemed hesitant should join the hakbsharah. From their first placement (kibbutz Nahshonim) in the spring of 1949, the avant-garde of the movement- the two brothers Tullio Tzvi and Aldo Eldad Melauri (Adar) who had left on 1 November 1948 (with Tina Cohen)—wrote to another future historian and intellectual, Guido Gadi Valabrega, who in 1949 was hesitating between joining Tel Broshim or enrolling at university:

We consider quite a serious matter the doubts and hesitations about entering the hakbsharah or continuing higher education [...] Our opinion is that a technical preparation cannot justify postponing the entry into bakbsharah and, consequently, the alià (sic). The non-entry into bakbsharab at 19-20 years old (at the end of high or technical school) makes it very likely that young people who lag behind will be completely lost to the chalutzistic (sic) [pioneering] movement [...]. On the other hand, one should not think that having completed a university degree, places the chaver $(s i c)$ in a privileged position [...]. Physical labor is the fundamental factor of kibbutz life and the premise of each technical improvement. The difficulty of adaptation to physical work (especially for young people coming from the Italian Golà $(s i c)$ [Diaspora], so far away from manual labor) makes the urgent entry in hakbsharah more necessary, while a university education is likely to alienate further from this life. ${ }^{42}$

${ }^{41}$ Interview Aldo Eldad Melauri (Adar) and Gabriella Luzzati.

${ }^{42}$ INSMLI, Collection Valabrega, Corrispondenza Eldad Aldo Melauri, folder 17/1, letter from Eldad and Tzvi [Aldo and Tullio Melauri (Adar)] to Gadi [Guido Valabrega], Nahshonim, 7 March 1949. 
Valabrega ultimately chose the hakbsharah, at least for a while. Beyond the political and ideological dimension-which permeated the whole enterprise, but was more relevant for some than for others-there was a very strong generational pull to the hakbsharah, amplified by the peer group. As Idalba (Yael) Bassani said: "And then I joined the hakhsharah. I knew I would not stop there"; Donata Ravenna echoed: "When I entered San Marco, I knew I would go out at the port of Haifa." Bruno Gad Segre stated: "It was almost natural to join the hakbsharah and leave for Palestine." 43

There were other ways to keep in touch between the "here" and the "there": some of the veterans (Sergio Itzhak Minerbi, Corrado Israel De Benedetti, and Aldo Eldad Melauri for example) came back in the first few years as shelichim themselves; their task was to find and motivate new recruits for the movement, to direct their immigration, to organize new departures and, altogether, to keep the movement alive. ${ }^{44}$

From the 1950s onwards, in fact, the question of how to mobilize new youngsters appeared with increasing frequency in the correspondence, revealing that the movement was encountering some difficulties. A third way of communication between the two groups was the journal of the movement. "Hechalutz" published articles from Israel and from Italy in its various sections, "News from Aretz," "From Palestine they write," "Reports on political developments in Israel," "The reality of the kibbutz." This is not the place to analyze the contents of the articles published in "Hechalutz"; the paper, directed since 1946 by Luciano Forti, then by Ruggero Iair Minerbi and then by Marco Maestro between 1950 and 1952, remains one of the main sources to study not only the relations between the two groups, but also the history of this youth movement, and its complex relations with Italian Jewish communities and their institutions. ${ }^{45}$

${ }^{43}$ Individual interviews of the author with Idalba (Yael) Bassani, Donata Ravenna, and Bruno Gad Segre, Haifa, 28 July 2009.

${ }^{44}$ INSMLI, Collection Valabrega, Tullio Zvi Melauri, folder 16, letter from Tzvi [Tullio Melauri (Adar)] to Gadi [Guido Valabrega], Ruhama, 27 January 1950, about the imminent departure from Israel of his brother's Aldo Eldad as shaliach.

${ }^{45}$ INSMLI, Collection Valabrega, folder 292, Marco Maestro, "Un Kaddish per Stalin," also available at http://www.hakeillah.com/5_03_37.htm, accessed 4 November 2016. The journal Hechalutz was directed by Luciano Forti (1946-1948), Ruggero Iair Minerbi (1949), Corrado Vivanti (1950), Marco Maestro (1950-1953), Mario Sciunnach (1953-1954), Dario Di Capua (1954) and, finally, Giuseppe Franchetti (1954-1956). 
Some of the letters between the two groups, the articles in the periodical publication "Hechalutz" and other written and oral material allow us to follow this group further, by looking at three more issues which marked their history as the first group of young Italian migrating to a kibbutz: first, the discussions on which kibbutz to go to; second, how to maintain the movement going once the first cohorts left; finally, what happened if someone decided to leave the group, the kibbutz and the movement altogether, for personal, family, or political reasons. These three last points intertwine at several junctions.

\section{Some Internal Conflicts and Divisions}

At the beginning of the 1950s two parallel processes invested "generation 1948." On the one hand, in Italy, the wave of enthusiasm of the younger generation for pioneering Zionism started to settle, and the presences in the hakbsharah began to diminish. One of the most active members of this group, Corrado Uri Vivanti (Chaim), reported in June 1950 that the hakhsharah counted 19 members, which became 10 when cohort 1950 left. In the same collective letter, he also warned of the renovated presence at Tel Broshim of shelichim from various kibbutz movements "hunting for our precious skins." Lot Minerbi of Kibbutz Ha-Meuchad was one of them, trying to push the new cohorts to kibbutz Regavim (where indeed several of them went). ${ }^{46}$ The group at Tel Broshim looked at the progressive normalization of Italian Jewish life with increasing preoccupation as Vivanti was writing:

If the Hachasharah $(s i c)$ closes, you can be sure that no one in Italy will speak of practical Zionism for a long time. The only thing that one can see is that really Italian Jewry is dead and we feel the consequences here. The only thing that is worthwhile is the kidnapping of the youth. We are the only ones left with some living energy. And so, let's move on; ad matai [until when?]. ${ }^{47}$

Marco Maestro's recollections of the time he spent at Tel Broshim in the following couple of years are similar; despite his attempts to attract to

${ }^{46}$ INSMLI, Collection Valabrega, folder 43, letter from Corrado Uri Vivanti (Chaim) to the comrades that have left Cevoli for Israel, S. Marco, 14 June 1950.

${ }^{47}$ INSMLI, Collection Valabrega, folder 43, letter from Corrado Uri Vivanti (Chaim) to the comrades that have left Cevoli for Israel, S. Marco, 5 October 1950. 
the hakbsharah young Jews from the ghetto of Rome, he ended up leaving for Israel in 1952 with only one friend, Nathan Mestre, who had not participated in the hakbsharah and did not originate from the ghetto of Rome. His recollections shed some light on the twilight of this pioneering Italian experience:

When I left, Cevoli did not have much time left to live. Also for this reason, the preparation received in haksharà $(s i c)$ had increasingly become some sort of rite of passage, a rite of separation from the Italian surrounding reality, more than a real preparation to the kibbutz. ${ }^{48}$

On the other hand, in Israel, during the same period, the kibbutz was also changing as an institution: it had become central in the absorption of new immigrants and progressively more involved in the bitter and divisive controversies that marked the Israeli Left in this period. Jews migrating to Israel in the 1950s came from non-European lands, and they belonged to political traditions that were very far from collectivist socialism, thus exacerbating the fallacies of a system that, as Vivanti had written, "hoped for a state built through socialism" but "closed [its] eyes in front of the needs of the kibbutz galuiot [sic, ingathering of the exiles]." The Italkim that immigrated in the early 1950s thus landed in a political reality and social organization that they struggled to recognize, and necessarily had to reassess and rescale the myth of the kibbutz as a place where to realize a revolutionary and transforming socialism, at least as they had imagined it in the hakhsharah. This detachment between expectations and reality took many forms. One of them was a generational rebellion that still kept the group within the broader kibbutz movement; another was political disillusionment that led to further splits inside the group, and also to the first renunciations and returns to Italy. The much-celebrated unity of Italian Jews did not stand the test of their arrival in Israel.

Indeed, writing in the periodical "Hechalutz" in 1950, Corrado Israel De Benedetti explained the overall differences between the hakbsharah in the Diaspora and the Israeli reality of the kibbutz: the first was to be understood as a moment of transition marked by youth and by a very strong collective striving for an ideal; the second was a permanent settlement, a testimony to the realization of that ideal. ${ }^{49}$ While in hakbsharah, the group

\footnotetext{
${ }^{48}$ INSMLI, Collection Valabrega, folder 292, Marco Maestro, "Ricordi dell'Hechalutz."

${ }^{49}$ [Corrado] Israel [De Benedetti], "Hachsciarà (sic) e kibbutz," Hechalutz 5/9, 7 Shevat 6510 - 25 January 1950: 2.
} 
discussed and voted on which kibbutz they would go to once in Israel. The avant-garde writing from Israel and the shelichim that had returned to Italy oriented the first cohorts of "generation 1948" to the newly established kibbutz Ruhama (Kibbutz Artzi) in the Negev, according to the political alignment that Minerbi, De Benedetti and others had impressed upon the movement. For example, in 1949 Tullio Tzvi Melauri (Adar) wrote from Israel how "Ruhama offers the best opportunities" to receive Italian Jews also because it "[would] open the movement in Italy." 50

The first splits occurred in 1950, when the groups from Tel Broshim opted for kibbutz Karmia, not far from today's Ashkelon, instead of Ruhama. In accordance with the spirit and the ideology of the time and of the whole enterprise, this was an emotionally and politically charged decision; it represented a rebellion by the younger members and indeed it was received as a betrayal by the "elders." After learning of the choice of cohort 1950 at Tel Broshim, its shaliach Aldo Eldad Melauri (Adar) wrote them a long and dramatic letter where, in a continuous crescendo, he described their decision as an attitude, a mistake, an abdication, cowardice, and a huge blow to his work. ${ }^{51}$ More easily after many years, Gabriella Luzzati, a member of that rebellious group, then Aldo Eldad's girlfriend and today his wife, explained:

I will tell you what Karmia was: when we came here [Ruhama], our group (that was the second to arrive) found that the previous groups had become bourgeois, Corrado [De Benedetti] and others, they had small children, and wanted to stay at Ruhama. And when we arrived as a group, without children and without nothing, we became fixated with the idea of establishing a new kibbutz. [...] All of us in the second group felt that this kibbutz hereestablished five years before-was old. ${ }^{52}$

One should also add that Ruhama was at the time absorbing a group of newly arrived Tunisian Jews, whose relations with the Italkim were difficult. For a similar rebellion, another small group (Idalba Yael and her husband Umberto Bassani, Donata Ravenna and Bruno Gad Segre, Luisa

\footnotetext{
${ }^{50}$ INSMLI, Collection Valabrega, Tullio Zvi Melauri, folder 16, letter from Tzvi [Tullio Melauri (Adar)] to Gadi [Guido Valabrega], Nahshonim, 16 September 1949.

${ }^{51}$ INSMLI, Collection Valabrega, Aldo Melauri a Corrado De Benedetti-Shoshanna, folder 43, letter from Eldad [Aldo Melauri (Adar)] to the chaverim [group] Tel-Broshim, 29 June 1950.

${ }^{52}$ Interview Aldo Eldad Melauri and Gabriella Luzzati.
} 
Minerbi and her husband Bruno Levi) chose kibbutz Regavim, founded in 1950 by 50 Italian and 50 North African Jews. For similar reasons-very hard working conditions and the difficulty to integrate with a group of Jews from a very different background - they all left within a few years. Somewhat anticipating his peers, Vivanti wrote about some of the contradictions that they all found when they arrived in the kibbutz: "It is useless to accuse the kibbutz of not knowing how to absorb the alià $(s i c)$. It is very well known that it is not possible to make live in a post-revolutionary climate those that not only do not know what the revolution is, but that actually oppose it." ${ }^{53}$ The Levis left Regavim and moved to Ruhama to rejoin the original group, while for the others Regavim represented the last stop of the collectivist experience.

\section{Some Returns}

Vivanti and Valabrega articulated their doubts, and later their disillusionment with the kibbutz, in political terms. This had little to do with a broader political analysis connected to the conditions in which the State of Israel was established, the Nakba or the incorporation of Palestinian lands in Ruhama as absentee property lands. Their analysis was conducted along Marxist categories, namely to what extent could the kibbutz be a transformative tool for the creation of a Socialist society in Israel; and to what extent were Jewish immigrants (and Italian Jews in particular) able to shrug off their own petite bourgeois legacy. Already in 1950 Vivanti had started to describe Israel as "running towards the bourgeois state," the Histadrut [trade union] "burdened by religious influences," and the kibbutz as "turning into something closer to a cooperative [...] or an oasis, an isolated community like many others that have flourished and decayed in many other countries." 54 The fierce political rifts within the Israeli Left in the early 1950s complicated the situation further; at their core stood the question whether Israel should remain anchored to the USSR (as the small communist party Maki, and the pro-Soviet Mapai-and thus Ha-Shomer Ha-Tza ir and Kibbutz Artzi-were holding), or move closer to the Western sphere, following Ben-Gurion's leadership and Mapam. The crisis within the Israeli left precipitated in 1952-1953, when the

${ }^{53}$ INSMLI, Collection Valabrega, folder 43, letter from Corrado Uri Vivanti (Chaim) to the comrades that have left Cevoli for Israel, S. Marco, 14 June 1950.

${ }^{54}$ Ibid. 
Doctors' Plot in the USSR and the Slánský trials in Czechoslovakia-both of which saw Communist regimes sentencing Jews to death with the accusation of betraying their homelands and, in the latter case, of favoring illegal immigration to Israel—caused all kibbutz movements, individual settlements, and every kibbutz member to take a stand for or against affiliation to the USSR, thus cracking the kibbutz movements open. ${ }^{55}$ As with all members of a kibbutz, the Italkim of "generation 1948" were also drawn into these dynamics, some in harsher ways than others.

In 1952, Valabrega had become a member of kibbutz Ruhama and, soon after, he was called to serve in the Israeli army. His diary "Notes from the barracks" appears as the story of a suspended time, a perpetual waiting between training and rest, a progressive loss of illusions, hopes, intellectual abilities, and a frequent return to family memories. In 1953 Guido Gadi Valabrega wrote an article for "Hechalutz" in which he ultimately described Israel as a capitalist state like all others. ${ }^{56}$ The article cost him dearly: in the heated climate of the post-Slánský affair, he was expelled from Ruhama on 15 August $1953 .{ }^{57}$ He then joined a splinter group from kibbutz Yad Hanna that established the smaller nearby kibbutz Yad Hana Senesh and became known as the only communist kibbutz. There he found Tullio Tzvi Melauri (Adar), Marco Maestro, and other Italkim from kibbutz Amir, among whom Nella De Benedetti, the sister of Corrado Israel, Alessandro Alex Sternberg, Sara Todros and her husband Dov Shalom. ${ }^{58}$ In the same year Valabrega returned to Italy on leave from the army for family reasons, ${ }^{59}$ did not go back to Israel and was thus declared a deserter, never being able to set foot in Israel again.

Corrado Vivanti, too, went back to Italy in 1953 for family reasons; upon arrival, the authorities blocked his passport for draft dodging in Italy, and he did not have the courage to immigrate to Israel illegally. $\mathrm{He}$

\footnotetext{
${ }^{55}$ See Joel Benin, Was the Red Flag Flying There? Marxist Politics and the Arab-Israeli Conflict in Egypt and Israel, 1948-1965 (Berkeley: University of California Press, 1990).

${ }^{56}$ INSMLI, Fondo Valabrega, Gadi [Guido Valabrega], folder 31, "Stato-KibbuzPartito," Hechalutz, 8/10 15 Luglio 1953-3 Av 5713, 2.

${ }^{57}$ See INSMLI, Fondo Valabrega, folder 50, for the original report of the assembly in which Valabrega was expelled. The translation from Hebrew into Italian is in INSMLI, Fondo Valabrega, folder 292.

${ }^{58}$ INSMLI, Fondo Valabrega, Tullio Zvi Melauri, folder 16, Letter from Tullio Tzvi Melauri (Adar) to Gadi Guido Valabrega, Ruhama, 24 November 1954.

${ }^{59}$ INSMLI, Fondo Valabrega, Corrispondenza Eugenia Zargani, folder 22/, [n.d.] and 26 August 1953.
} 
thus enrolled in university to postpone military service, later became a member of the Italian Communist Party (PCI) and ultimately decided that the Party, more than the kibbutz, would be the instrument for liberation and revolution. This stand was strongly resented by the rest of the group, who judged his non-return as a betrayal. A letter from Tullio Tzvi Melauri (Adar) to Guido Gadi Valabrega shows how the news of Vivanti's non-return was received:

We have received a long letter from Uri [Corrado Vivanti] that caused a great sensation in us all. [...] In short, Uri says that in Italy he found many nice things, and among them "wandering around newsstands and bookshops hunting for interesting books etc." In any case, he was getting ready to come back when his mother notified him in Rome that the Carabinieri had called him [to be enlisted in the Italian army for compulsory military service]. He showed up, not giving too much weight to the call, relying on certain protekzie [sic]. Then things turned complicated. [...] On his decision not to come back your issue also played a role $[\ldots]$ as he shared your pessimism towards the Israeli workers' movement etc. Moreover, given his political stands, he did not see any sikuim [chances, sic] to stay in Ruhama, and he did not feel like moving to the city. [...] His letter caused a massive scandal among us, and everyone accuses him of treason, of choosing the easy life, of being spoiled. Personally, I am sorry I have lost a good friend, though such a development could be easily anticipated lately. ${ }^{60}$

After their studies, Vivanti and Valabrega became well-known academics, public intellectuals, who took very strong anti-Zionist stands in Jewish communities as well as in the circles of the PCI, Valabrega more publicly and more outspokenly than Vivanti. Corrado Israel De Benedetti, who had returned to Italy as shaliach at Tel Broshim between 1952 and 1954, felt that his work was in part undermined-and misrepresented-by these two uncomfortable witnesses, and he vigorously opposed their interpretation and public presentation of the Israeli reality. As he wrote in 1953 to Valabrega, "a farmer or a worker Jew" is a "more faithful comrade than an intellectual with trappings of the party," further elaborating on this concept the following year:

${ }^{60}$ INSMLI, Fondo Valabrega, Tullio Zvi Melauri, folder 16, Letter from Tullio Tzvi Melauri (Adar) to Gadi Guido Valabrega, Ruhama, 21 September 1953.

${ }^{61}$ INSMLI, Fondo Valabrega, folder 16, Letter from Corrado Israel De Benedetti to Guido Valabrega, [n.d.], 1953? 
I will restore completely my esteem in you only when you will return there [in Israel]. Otherwise I'll have to draw the conclusion that you choose the path of revolution where it is easier, which I think is not very dignified for a good Marxist-Leninist. And I also have to think that this is true not only from a moral point of view (a strong PCI rather than a scanty MAKI), but also from a material perspective, so that of course your family circumstances allow you to prefer Italy to Israel, this country with more than $1,000,000$ unemployed workers, with hunger in the South, poverty etc., all things that, however, fortunately, are far away from you. ${ }^{62}$

These words revealed not only a completely divergent political vision, but also a personal unbridgeable distance that separated some of the members that had belonged to the same peer group and youth movement. Before De Benedetti, who continued "to believe in the revolutionary role of the 'alyia [sic]," stood Vivanti, who considered the historical necessity of Jewish immigration to Israel "a reactionary falsehood" particularly unsuited to the Italian case. ${ }^{63}$ Already in 1953-1954 Vivanti was looking bitterly at this experience, seeing it as a "parenthesis" and as a personal utopia that he really had believed to be collective, Jewish, and socialist, but "which had passed like a summer storm" and to which he "he had dedicated among the best years of [his] life." ${ }^{64}$ This was more than a generational rift inside a peer group and it continued to be present in the collective memory of that early experience until very recently, on both sides. Still in 1997 Valabrega wrote to De Benedetti, asking that his expulsion from Ruhama be revised; and while Valabrega was looking for a late rehabilitation, he obtained a statement from De Benedetti to the effect that "his expulsion for political reasons in 1953 could have been avoided." ${ }^{65}$

Others also went back to Italy: among them was Tullio Tzvi Melauri, who left the kibbutz wondering "why one should work as a farmer, having so little inclination for it," $" 66$ and who settled in Florence. Marco Maestro

${ }^{62}$ INSMLI, Fondo Valabrega, folder 16, Letter from Corrado Israel De Benedetti to Guido Valabrega, [n.d.], 3 December 1954?

${ }^{63}$ INSMLI, Fondo Valabrega, folder $22 / 2$, Letter from Corrado Vivanti to Guido Valabrega, 25 January 1954.

${ }^{64}$ Ibid., Letters from Corrado Uri Vivanti to Guido Gadi Valabrega, 4 December 1953 and 19 April 1954.

${ }^{65}$ Paolo Valabrega, Gadi. Ascesa e caduta di un giovane socialista sionista. Un'introduzione alle carte 1942-1953 del Fondo Guido Valabrega nell'Archivio INSMLI a Milano, Tesi di laurea non pubblicata, Università di Milano, a.a. 2006-2007, 103-105.

${ }^{66}$ INSMLI, Fondo Valabrega, Tullio Zvi Melauri, folder 16, Letter from Tullio Tzvi Melauri (Adar) to Gadi Guido Valabrega, Jd-Hanna (sic), 5 September 1954. 
also went back to Italy in 1954, on a temporary visit that turned into a permanent stay after meeting his baby daughter for the first time. He, too, became a member of the PCI.

Not surprisingly, the narrative and the memory of the returnees stand in stark contrast to the narrative and memory of those who stayed in Israel. The dream of Corrado Israel De Benedetti, and of the others who had first come into contact with the JB and with Savaldi and Silica did not come true. At the time, De Benedetti wrote how they dreamt "of a movement that could be a mass movement, that would depopulate Italian Jewish communities within a few years." ${ }^{67}$ However, already in 1950 "Hehchalutz" was speaking of a few interested youngsters, "the rare ones that are interested to the call of Eretz Israel." ${ }^{68}$ In 1951, the Irgun Olei Italia (sic) presented some data on Italians in Israel in that year: there were about 1199-1299 Italkim in Israel, with 300 children born in loco. Some 510 had arrived before 1945 (69 went back). Between 1945 and 1948, 300 people had immigrated and 90 arrived after 1948 (50 of whom went back). ${ }^{69}$

Corrado Israel De Benedetti remained as one of the movement's leaders and settled in Ruhama, where he raised his family and where he lives to this day. His next-door neighbors are Aldo Eldad Melauri (Adar) and Gabriella Luzzati, Bruno and Luisa Levi, and a few others who immigrated from Tel Broshim. Idalba Yael Bassani, Donata Ravenna, and Bruno Gad Segre live in Haifa. Sergio Itzhak Minerbi, one of the very first leaders of this movement, also left Ruhama in 1956 and moved to Jerusalem. Like Vivanti, but from a different perspective, he had also reached the conclusion that the kibbutz, intended as the main means for immigrant absorption, was really unable to integrate the hundreds of thousands of Jews coming to Israel from Arab countries, due to the lack of interest and ability of the leaders of the kibbutz movements. ${ }^{70}$

For all, it was the combination of the post-war circumstances, and of personal and political factors that pulled them to the movement, to Zionism and to the kibbutz, and that pushed some of them out of it and back to Italy, in different ways. The words of Idalba Yael Bassani, the

${ }^{67}$ Interview with De Benedetti.

${ }^{68}$ Eliahu Dobkin, "Ritorniamo al chalutzismo," Hechalutz 5/5-6, 14 Chislev 5710 - 5 December 1949: 1-2.

${ }^{69}$ INSMLI, Fondo Valabrega, Irgun Olei Italia di Tel Aviv, Irgun Olé (sic) Italia, 17 June 1951.

${ }^{70}$ Interview with Minerbi. 
youngest of "generation 1948," well summarize the historical moment that they all lived through, and that each of them interpreted in different and, at times, diverging ways:

The history in itself is not exceptional; it was the times that were incredible. In 1945, I was 14 years old. And to breathe the political climate of Turin in those times, at that age, was something that marked my whole life; it was the postwar years and there was an atmosphere of enthusiasm, of freedom, and an incredible energy, and everything was possible. ${ }^{71}$

\section{Conclusions}

"Generation 1948" developed their own response to the momentous changes that invested Italian Jewry during and after the war, identifying practical Zionism and the kibbutz as the main, if not the only, way to save themselves and future generations of Italian Jews from losing their cultural identity and national specificity. In this way, they rebelled not only against their parents who had been on the whole unable to detect the impending danger before and during the war, and thus to protect their children and themselves from persecution; they also reacted to the idea that Italian Jews would remain (once again) detached from the social and cultural trends that were transforming world Jewry. For many of "generation 1948" the soldiers of the JB represented the first encounter with another way of being Jewish than the one they had experienced in Italy until then. The shelichim who had arrived in Italy from several religious and political streams and who were "hunting for [our] precious skins," to quote Vivanti, represented yet another model that "generation 1948" saw in action and in some cases imitated, for example with the return at Tel Broshim of Aldo Eldad Melauri Adar and Corrado Israel De Benedetti as shelichim for Hechalutz between the late 1940s and the early 1950s. As we have seen, after their pioneering experience, not all of those who belonged to this group remained in the kibbutz or even in Israel. Regardless of the ultimate decision of each individual about his or her life, their collective experience succeeded in reconnecting Jews in Italy with the Zionist movement on a global scale. This was not enough to turn them into examples to be followed, though, and successive generations chose other paths to maintain this connection with Zionism and the State of Israel, and to

\footnotetext{
${ }^{71}$ Interview with Bassani.
} 
elaborate on the meaning of the Italian Jewish experience during the war. Still, the path of "generation 1948" remained crucial because it allowed for the initial connection to be made. New emissaries from Israel arrived in Italy in the 1950s and 1960s; these were shelichim of the Jewish Agency or, more unofficially, Israeli students at Italian universities. In various Jewish communities-among them Milan, Turin, and Florence-they became reference points for the generation of Jewish youth born after the war. Like their predecessors, the young adults who belonged to this group were also attracted to Israel and the kibbutz and to the legendary status of pioneering Zionism; however, unlike them, some had already had the opportunity to visit the country, whether for family reasons or with some organized trip. The new shelichim were active in Jewish communities and often tutored them: they taught Hebrew and/or gymnastics; they encouraged youngsters and families to visit Israel on holiday; in various instances, they accompanied the local Jews to university meetings and discussions where the Middle Eastern question was discussed, often with inflammatory tones. ${ }^{72}$

In the meantime, the once marginal Jewish Italian scene had become populated with other local and international agents that further promoted exchanges between Italian Jews, Italkim, the State of Israel, and Jews from other countries, for example through the activities of two transnational Jewish youth movements, Ha-Shomer Ha-Tza'ir and Bnei 'Akivah. Here we cannot discuss in detail the political reasons behind their arrival and spread in Italy, the Zionist activism they promoted, their different political orientations, and their long-term impact among successive generations of Italian Jews. However, it is interesting to note, on the one hand, their inevitable rivalry with the Federazione Giovani Ebrei d' Italia (FGEI, Federation of Young Jews of Italy), a left-wing and non-Zionist organization established in Florence already in March 1948. This organization was meant to help Italian Jews establish connections also within their own country and not only within a transnational perspective of immigration and resettlement. ${ }^{73}$ On the other hand, it is important to note the coinci-

\footnotetext{
${ }^{72}$ Interviews by the author with Piero Avner Calò, Magan Michael, 22 July 2009; Daniele Ventura, Raanana, 22 July 2009; Lia Pacifici Millul, Haifa, 27 July 2009; Marina Ergas, Jerusalem 3 August 2009; and Liana E. Funaro (high school teacher at the Jewish Secondary School of Milan in 1960-1962), Florence, 10 May 2010.

${ }^{73}$ Giovanni Battista N. Paglianti, "Profilo dell'associazionismo giovanile ebraico," in $E l i$ insegnerai ai tuoi figli. Educazione ebraica in Italia dalle leggi razziali a oggi, ed. Anna Maria Piussi (Florence: Giuntina, 1997), 201-209; idem, "Aspetti socio-antropologici dei movi-
} 
dence between the emergence of these new protagonists in the first half of the 1950s and the gradual fading of the pioneering experience of Hechalutz, with smaller numbers at Tel Broshim, a less frequent publication, and no clear heir to their experience, as Vivanti, Valabrega, and De Benedetti had all foreseen.

In June 1967-responding to the much-feared threat that a new Holocaust would take place with the imminent annihilation of the State of Israel-1 10 young Jews from Northern and Central Italy left as volunteers to work in various kibbutzim, often arriving after the war's end for obvious logistical reasons. A table in the autonomous journal "The Volunteer/ HaMitnadev" (which was published by the Jewish Agency) summarized the number of Jewish (and the few non-Jewish) volunteers that had flocked to Israel in the months of June-August 1967, as a total of 5043 individuals from various countries. The publication was obviously trying to capitalize on the arrival of so many new youngsters, building on their feeling of participating in an exceptional experience- - a feeling that they all shared and that many of them still convey through their own accounts of those days. Indeed, the number of Jewish volunteers had grown to 7215 by October. ${ }^{74}$

Regardless of who stayed and of who came back from Israel during the long summer of 1967, it is interesting to note that, twenty years after 1948 , not much was left of the Italian specificity and marginality that "generation 1948" had reacted against. While still thinking and acting in several different ways on the crucial issues concerning contemporary Judaism, by this time young Italian Jews were now broadly in line with most Jewish youth in Europe and the world.

menti giovanili Hashomer Ha-tsair e Bnei Akiva," in Presto apprendere, tardi dimenticare: l'educazione ebraica nell'Italia contemporanea, ed. Anna Maria Piussi (Milan: Franco Angeli, 1998), 112-36. See also Schwarz, After Mussolini, 83-92.

${ }^{74}$ On "Generation 1967," see Simoni, “Gli ebrei italiani e lo Stato di Israele," esp. 57-66. See also HaMitnadev / The Volunteer, 1, Tammuz 5727 - July 1967, 8 for a comparative table of Jews volunteering divided by national provenance. The largest group came from the UK (1400) followed by South America (1200); South Africa (860); France (800); USA (500); Canada (300); Belgium (285); Switzerland, Austria, Spain, and Germany (262); Australia (150); Scandinavia (135); the Netherlands (90). See also “The Volunteers' Convention," HaMitnadev / The Volunteer 3, Tishri 5728 - October 1967: 1. 